\author{
Case Study \\ www.ijrap.net (ISSN:2229-3566)
}

\title{
ROLE OF VYATYASA CHIKITSA IN MANAGEMENT OF GREEVA STAMBHA (CERVICAL SPONDYLOSIS): A CASE STUDY
}

Bishnoi Poonam ${ }^{* 1}$ and Kumar Pankaj ${ }^{2}$

${ }^{1}$ BAMS Final Year, Ayujyoti Ayurvedic College and Hospital, Sirsa, Haryana, India

${ }^{2}$ Assistant Professor, Department of Panchakarma, Ayujyoti Ayurvedic College and Hospital, Sirsa, Haryana, India

Received on: 21/01/20 Accepted on: 21/03/20

\begin{abstract}
*Corresponding author
E-mail: poonamgill473@gmail.com
\end{abstract}

DOI: 10.7897/2277-4343.110350

\begin{abstract}
Cervical spondylosis is a chronic degenerative condition of cervical spine. It is one of the most common degenerative disorders of spine affecting $95 \%$ of patient by the age of 65 years. The disease cervical spondylosis and Greeva Stambha are similar in their etiology, signs and symptoms. Greeva Stambha is a Shoolapradhana Vatananatmaj Vyadhi affecting musculoskeletal system and leaving the person disable from daily routine activity. In this case a 63 years old female having chief complain of severe pain and stiffness over the neck especially after waking up in the morning since one and half month. She also has burning type shoulder pain bilaterally, on and off type of pain in bilateral upper limb from 12 years and restricted movement of neck. She is also suffering from headache, heaviness in the neck region. Special test for cervical spondylosis like Spurling test, Compression test, swallowing test, Distraction test and active or passive range of motion is carried out for the proper diagnosis. After thorough examination, a diagnosis of Greeva Stambha vis-à-vis cervical spondylosis has been established. Treatment includes Tusha Pinda Sweda, Greeva Basti, Pratimarsha Nasya, Rakta Mokshana, Takradhara and certain medicinal formulations. The treatment was found to be efficacious in the whole symptoms of Greeva Stambha. Patient got $90-95 \%$ relief in all sign and symptoms. This was a pilot trial done on a single case.
\end{abstract}

Keywords: Vyatyasa Chikitsa, Greeva Stambha, cervical spondylosis and Tusha Pinda Sweda

\section{INTRODUCTION}

Cervical spondylosis is a condition which causes deterioration of the vertebrae, disc and ligament in the neck or cervical spine. Morning stiffness is a characteristic feature. In chronic condition, the pain may be worse at night or after neck movement. Cervical spondylosis is a common condition i.e. estimated to account for $2 \%$ of all hospital admission. On the basis of radiological findings $90 \%$ of men older than 50 years and $90 \%$ women older than 60 years have evidence of degenerative changes in cervical spine. Evidence from a 2009 report indicated that cervical spondylosis with myelopathy was the most common primary diagnosis (36\%) among elderly. ${ }^{1}$

In Ayurveda, cervical spondylosis is correlated with Greeva Stambha which is one of the 80 types of Vata Vyadhi. Vyana vayu is responsible for the movement of body. ${ }^{2-4}$ Greeva Stambha in which Stambha (stiffness) is developed in the neck region. Acharya Sushruta has described Manyastambha which caused by diwasawapana ${ }^{5}$ using pillows inappropriately during sleeping, leading to the vitiation of Vata and kapha dosha such as condition of Cervical spondylosis.

Ayurvedic treatment protocol is primarily focused on normalizing the vitiated dosha by means of Sodhana and shaman therapy. The Panchakarma treatment Snehana and Swedana are considered as a general line of treatment for Vata Vikara which are Vatakaphahara and Shoolahara. Snehana helps in nourishing the Dhatu and increasing the Agni bala and helps in increasing the strength of body. Also helps in relieving pain and stiffness by pacifying the vitiated vatahara. ${ }^{6}$ Swedana has tikshna and ushna property has its main action like stambhaghna, gauravghna, shitaghna which are quite opposite to the symptoms of this diseases. In vata kapha diseases to break Kaphavarana Ruksha
Swedana is to be adopted in case of symptoms like heaviness. ${ }^{7}$ Ruksha Swedana like Tusha Pinda Sweda, Churna Pinda Sweda and Baluka Sweda etc. is ideal treatment to break kapha avarana.

\section{MATERIAL AND METHODS}

A 63 years old female has visited OPD with chief complain of severe pain and stiffness over the neck especially after waking up in the morning since one and half month. She also has burning type shoulder pain bilaterally, on and off type of pain in bilateral upper limb from 12 years and restricted movement of neck. She is also suffering from headache, heaviness in the neck region and incomplete evacuation of bowels. General health issues included 4 years history of thyroid and in family her brother is known case of D.M. Study is carried out as per International conference of Harmonization-Good Clinical Practices Guidelines (ICH-GCP) or as per Declaration of Helsinki guidelines.

\section{Examination}

Special test for cervical spondylosis like Spurling test, Compression test, swallowing test, Distraction test and active or passive range of motion is carried out for the proper diagnosis. After thorough examination, a diagnosis of Greeva Stambha visà-vis cervical spondylosis has been established and patient is advised for Tusha Pinda Swedana, ${ }^{8}$ Greeva Basti, Pratimarsha Nasya, Takradhara, Rakta Mokshana with oral Ayurvedic medication.

\section{Treatment plan}

A schedule has been planned with Tusha Pinda Swedana, Greeva Basti, Pratimarsha Nasya, Takradhara and Rakta Mokshana. 
Table 1: Shodhana Chikitsa

\begin{tabular}{|c|c|c|}
\hline 1. & Greeva Basti & Karpasasthyadi Taila \\
\hline 2. & Pratimarsha Nasya & Karpasasthyadi taila \\
\hline 3. & Takradhara & Amalaki Churna and Musta Churna \\
\hline
\end{tabular}

Along with this, patient is advised to take following Ayurvedic medicine throughout the treatment schedule

\section{Table 2: Shamana Chikitsa}

\begin{tabular}{|c|c|c|}
\hline 1. & Churna & 5 gm BD with honey (after food) \\
\hline 2. & $\begin{array}{c}\text { Avipatikara Churna }-75 \mathrm{gm} \\
\text { Godanti Bhasma }-5 \mathrm{gm} \\
\text { Ajmodadi Churna }-75 \mathrm{gm}\end{array}$ & 2 BD (after food) \\
\hline 3 & Trayodashanga Guggulu & $20 \mathrm{ml}$ TID (before food) \\
\hline
\end{tabular}

\section{Assessment Parameter}

1. Neck Pain

2. Neck stiffness

3. Neck rotation

4. Headache

5. Burning pain in shoulder
Grading parameter

Table 3: Neck Pain

\begin{tabular}{|c|c|}
\hline Grade & Observation \\
\hline 0 & No Pain \\
\hline 1 & Mild and Intermittent Pain \\
\hline 2 & Moderate and Bearable Pain \\
\hline 3 & Severe and Unbearable Pain \\
\hline
\end{tabular}

Table 4: Neck Stiffness

\begin{tabular}{|c|c|}
\hline Grade & Observation \\
\hline 0 & No Stiffness \\
\hline $\mathbf{1}$ & Up to 25\% Impairment in range of movement. Patient can do daily routine without any difficulty \\
\hline $\mathbf{2}$ & Up to $25-50 \%$ Impairment in range of movement. Patient can perform daily routine with mild/moderate difficulty. \\
\hline $\mathbf{3}$ & Up to $50-75 \%$ Impairment in range of movement. Patient can perform daily routine activity with moderate to severe difficulty \\
\hline $\mathbf{4}$ & $>75 \%$ Impairment in range of movement. Patient totally unable to do daily routine. \\
\hline
\end{tabular}

Table 5: Neck Rotation

\begin{tabular}{|c|c|}
\hline Grade & Observation \\
\hline 0 & Possible without any difficulty \\
\hline 1 & Possible with slight difficulty \\
\hline 2 & Possible with more difficulty \\
\hline 3 & Not at all possible \\
\hline
\end{tabular}

Table 6: Headache

\begin{tabular}{|c|c|}
\hline Grade & Observation \\
\hline 0 & Absent \\
\hline 1 & Occasional \\
\hline 2 & $1-3$ times in a week \\
\hline 3 & $>3$ times in a week \\
\hline
\end{tabular}

Table 7: Burning Pain in Shoulder

\begin{tabular}{|c|c|}
\hline Grade & Observation \\
\hline 0 & Absent \\
\hline 1 & Mild and Intermittent Pain \\
\hline 2 & Moderate and Bearable Pain \\
\hline 3 & Severe and Unbearable Pain \\
\hline
\end{tabular}

\section{RESULT AND DISCUSSION}

Observation before and after the course of treatment is as follows:

\section{Observation in different parameter}

Table 8: Result and Discussion

\begin{tabular}{|c|c|c|c|}
\hline S. No. & Parameter & Before treatment & After treatment \\
\hline 1 & Neck pain & 2 & 1 \\
\hline 2 & Neck stiffness & 3 & 0 \\
\hline 3 & Neck rotation & 2 & 0 \\
\hline 4 & Headache & 2 & 0 \\
\hline 5 & Burning pain & 2 & 0 \\
\hline
\end{tabular}

In Ayurveda main etiological factor for the development of Greeva Stambha is considered as vitiated vata and kapha dosha. In the present case study, Vyatyasa Chikitsa is adopted to manage Greeva Stambha with a prime focus to alleviate vata and kapha dosha. Tusha is Ruksha in nature and because of this Ruksha Guna it eradicates the kapha dosha. Vyatyasa Chikitsa is planned when two opposite doshas are vitiated in nearly equal amount. And because of opposite nature they need the treatment which 
balances both the dosha at same time so this Vyatyasa Chikitsa i.e. Tusha Pinda Sweda and Greeva Basti pacifies the kapha and vata dosha respectively and simultaneously. Tryodashanga Guggulu contain drugs like Shodhita Guggulu, Rasna, ashwagandha, babula, hapusa, satavari, gokshura, shatahva, shati, guduchi, vrudhadaru, sunthi, goghrita. Tryodashanga Guggulu drugs are having tikta, katu, kashaya rasa and ushna Virya and Madhur Vipaka. Due to ushna Virya and Madhur rasa it is vatahara and ushna virya and tikta, kashaya rasa is responsible to pacify the kapha dosha.

Sahacharadi kashaya contain drugs like sahachara, devdaru, shunthi useful in vatarogas. Dashmoola kwath is well known Ayurvedic medicine having anti-inflammatory, analgesics effect. Dashmoola kwath is having bhrita panchmoola and laghu panchmoola. Bhrita panchmoola drvyas are kashaya, tikta rasa pradhana, ushna Virya and kapha vata shamak. Laghu panchmoola drvyas are Madhur in rasa unushansheet and sarvadoshanasak

Karpasasthyadi taila contain drugs like karpasasthi, bala, masha kwath etc. It is useful in neuromuscular condition caused due to vata imbalance. It is mainly used in urdhwajatrugata vikaras.

In this study, patient was having neck pain with stiffness which gets significant relief after treatment.

\section{CONCLUSION}

It is concluded that Greevastambha is a vatakaphaja vyadhi. In this both vata and kapha are vitiated simultaneously. Then to pacify these doshas at same time vyatyas chikitsa is adapted. Here rukshan karma i.e. tusha pinda sweda pacify kapha dosha and Snehana karma i.e. karpasasthyadi taila Greeva Basti pacifies the vata dosha.

\section{REFERENCES}

1. Hassan Ahmad Hassan Al Shatoury. Cervical Spondylosis, Internet. Drugs and Diseases > Physical medicine and Rehabilitation. Cited 2018 March 30. Available from: http://www.emedicine.mediscape.com.

2. Charaka, Vatavyadhichikitsa adhyaya. In: Vidyotini Hindi commentary, Pandit Kashinath Shastri, Dr. Gorakhnath
Chaturvedi, Charaka Samhita Uttarardha Chikitsa sthana, reprint edition. Varanasi: Chaukhambha Bharati Academy; 2017. p. 777, 28: 9 .

3. Bharti, Katyal S, Kumar A, Makhija R, Devalla RB. Clinical observation on Greeva Stambha Chikitsa. An Int. Quarterly J. Res. In Ayurveda. Med know Publications and Media Pvt. Ltd. April-June 2010; 3(2): 218-222.

4. Sushruta, Vatavyadhi nidana adhyaya. In: Ayurveda Tattva Sandipika Hindi Commentary, Kaviraja Ambikadutta Shastri, Sushruta Samhita Purvardha Nidana sthana, reprint edition. Varanasi: Chaukhambha Sanskrit Sansthan; 2018. p. 297, 1: 17.

5. Sushruta, Vatavyadhi nidana adhyaya. In: Ayurveda Tattva Sandipika Hindi Commentary, Kaviraja Ambikadutta Shastri, Sushruta Samhita Purvardha Nidana sthana, reprint edition. Varanasi: Chaukhambha Sanskrit Sansthan; 2018. p. 303, 1: 67.

6. Sharma S, Bhusal N, Mangal G, Garg G. Cervical spondylosis and its Panchakarma Management: A Conceptual study. Int. Ayurvedic Medical Journal. Nov. 2017. Available from: $\quad$ http://www.iamj.in/posts/images/upload/4157 4160.pdf.

7. Vishwas SK, Sharma KK, Kumar A. Review on cervical Spondylosis and its management through Panchakarma. Ayushdhara 2018; 5(4): 1791-1795. Vol.5 issue 4.

8. Charaka, Sweda adhyaya. In: Vidyotini Hindi commentary, Pandit Kashinath Shastri, Dr. Gorakhnath Chaturvedi, Charaka Samhita Purvardha Sutra sthana, reprint edition. Varanasi: Chaukhambha Bharati Academy; 2015. p. 286, 14 : 26.

9. Kaushika R, Sharma P, Omprakash. Management of cervical spondylosis through Ayurveda: A case study. Int. J. Res. Ayurveda Pharma 2017; 8 Suppl 2: 179-181. http://dx.doi.org/10.7897/2277-4343.082109

\section{Cite this article as:}

Bishnoi Poonam and Kumar Pankaj. Role of Vyatyasa Chikitsa in management of Greeva Stambha (Cervical Spondylosis): A Case Study. Int. J. Res. Ayurveda Pharm. 2020; 11(3):10-12 http://dx.doi.org/10.7897/2277-4343.110350

\section{Source of support: Nil, Conflict of interest: None Declared}

Disclaimer: IJRAP is solely owned by Moksha Publishing House - A non-profit publishing house, dedicated to publishing quality research, while every effort has been taken to verify the accuracy of the content published in our Journal. IJRAP cannot accept any responsibility or liability for the site content and articles published. The views expressed in articles by our contributing authors are not necessarily those of IJRAP editor or editorial board members. 